\title{
Prevalence of metabolic syndrome and its components based on International Diabetes Federation (IDF) definition in Yogyakarta Special Region, Indonesia
}

\author{
Choo Hao Jian', Fatwa Sari Tetra Dewi ${ }^{2}$, Elizabeth Henny Herningtyas ${ }^{3 *}$ \\ ${ }^{1}$ Undergraduate Program of Medicine, ${ }^{2}$ Department of Public Health, ${ }^{3}$ Department of \\ Clinical Pathology and Laboratory Medicine, Faculty of Medicine, Universitas Gadjah \\ Mada, Yogyakarta
}

DOI: http://dx.doi.org/10.19106/JMedSci004903201705

\begin{abstract}
Metabolic syndrome (MetS) is a group of risk factors which increase morbidity and mortality for cardiovascular disease and diabetes. The prevalence of MetS has been on the rise. No previous study has described the prevalence of MetS in Yogyakarta Special Region and its components. The study aim was to determine the prevalence of MetS and it's components in Yogyakarta Special Region, Indonesia. A total of 766 male and female subjects aged $\geq 40$ were analyzed in this retrospective study based on secondary data from the Indonesian Family Life Survey batch 4 (IFLS 4). MetS was defined by International Diabetes Federation (IDF) criteria with ethnicity-specific values for waist circumference. Prevalence of MetS and characteristic of each component of MetS were expressed as mean or \%. The difference of the MetS components was evaluated by t-test and chi-square. Prevalence of MetS in Yogyakarta Special Region was $13.19 \%$. The most common of MetS component was hypertension (60.44\%), followed by dyslipidemia $(56.27 \%)$, central obesity $(32.38 \%)$, pro-inflammatory state $(15.71 \%)$ and insulin resistance $(0.78 \%)$. There was a higher prevalence of MetS in females compared to males ( 15.88 vs $10.19 \%$ ), pre-elderly compared to the elderly ( 13.90 vs $12.19 \%$ ), Javanese compared to other ethnicities ( 13.23 vs $10.00 \%$ ), and urban compared to rural populations (15.06 vs 8.37\%). In conclusion, the prevalence of MetS in Yogyakarta Special Region is $13.19 \%$ with hypertension and dyslipidemia as the most common components.
\end{abstract}

\section{ABSTRAK}

Sindrom metabolik (SM) merupakan sekelompok faktor risiko yang meningkatkan morbiditas dan mortalitas penyakit kardiovaskuler dan diabetes. Prevalensi SM mengalami peningkatan. Tidak ada penelitian sebelumnya yang memaparkan prevalensi SM dan komponennya di Daerah Istimewa Yogyakarta. Tujuan penelitian ini untuk menentukan prevalensi SM dan komponennya di Daerah Istimewa Yogyakarta, Indonesia. Sebanyak 766 subyek laki-laki dan perempuan berumur $\geq 40$ dianalisis pada penelitian retrospektif ini berdasarkan data sekunder dari Survei Rumah Tangga Indonesia angkatan 4 (SAKERTI 4). SM ditetapkan dengan kriteria International Diabetes Federation (IDF) dengan nilai spesifik etnisitas untuk lingkar perut. Prevalensi SM dan komponen SM dievaluasi

$\overline{\text { Corresponding author: ehennyh@ugm.ac.id }}$ 
Hao Jian et al., Prevalence of metabolic syndrome and its components based on International Diabetes Federation (IDF) definition in Yogyakarta Special Region, Indonesia

dengan uji t dan chi-square. Prevalensi SM di Daerah Istimewa Yogyakarta ialah 13,19\%. Komponen SM tersering ialah hipertensi $(60,44 \%)$, diikuti oleh dyslipidemia $(56,27 \%)$, obesitas sentral $(32,38 \%)$, kondisi proinflamasi $(15,71 \%)$ dan resistensi insulin $(0,78 \%)$. Didapatkan prevalensi SM yang lebih tinggi pada perempuan dibandingkan laki-laki (15.88 vs $10.19 \%$ ), pra-lansia dibandingkan dengan lansia (13.90 vs $12.19 \%$ ), orang Jawa dibandingkan etnis lain (13.23 vs $10.00 \%$ ), dan populasi perkotaan dibandingkan dengan pedesaan (15.06 vs 8.37\%), Sebagai simpulan, prevalensi SM di Daerah Istimewa Yogyakarta 13, 19\% dengan hipertensi dan dyslipidemia sebagai komponen tersering.

Keywords: Metabolic Syndrome - central obesity - dyslipidemia - hypertension, Yogyakarta Special Region, International Diabetes Federation.

\section{INTRODUCTION}

Metabolic syndrome (MetS) is a group of risk factors that commonly appear together, contributing to increased incidence of heart attack. The observed risk factors are known to be insulin resistance, abdominal obesity, atherogenic dyslipidemia, and high blood pressure. ${ }^{1}$ Studies show an increase in MetS prevalence in many developing countries, including the Philippines (19\%), Malaysia (24.2\%), Brazil (25.4\%), India (28.8\%), Venezuela (31.2\%), Turkey (33.4\%), and Iran $(33.7 \%){ }^{2}$ The MetS prevalence in previous studies from other regions of Indonesia are as follows: Bali (18.2\%), Bogor (18.7\%), Jakarta (28.4\%), Makassar (33.9\%), and Surabaya $(34.0 \%))^{3-6}$ However, information of MetS prevalence in Indonesia is incomplete, and most of the previous studies use World Health Organization (WHO) or National Cholesterol Education Program/Adult Treatment Panel III (NCEP/ATP III) criteria. No research describing the prevalence of the MetS in Yogyakarta, Indonesia using the International Diabetes Federation (IDF) definition is ever reported.

A 2011 survey shows that Yogyakarta's population has the highest life expectancy among Indonesians (73.27 years), thus the occurrence of chronic disease such as diabetes mellitus and MetS is predicted to increase. ${ }^{7}$ The Ministry of Health, Republic of Indonesia reported the prevalence of Non Communicable Diseases (NCD) risk factors in Yogyakarta Special Region as follows: low fruit and vegetable intake $(86.1 \%)$, physical inactivity $(45.3 \%)$, hypertension $(35.8 \%)$, smoking $(29.8 \%)$, heart disease $(7.3 \%)$, alcohol drinking $(3.2 \%){ }^{8}$ Interestingly, smoking prevalence in Yogyakarta Special Region is slightly higher than the national average prevalence $(29.8 \%$ vs $29.2 \%){ }^{8}$ Given the high prevalence of these unhealthy living habits coupled with an aging population, it is important to determine the prevalence of MetS in Yogyakarta Special Region.

In this study, the IFLS 4 data is used because it has a large sample, good sampling technique, and is easy to obtain. Contained within the IFLS 4 data are 4 out of 5 factors of MetS that can be used to determine the presence or absence of MetS in the population, so it has been used in this study together with certain demographic factors. The objective of this research was to determine the prevalence of MetS in Yogyakarta Special Region based on IDF criteria and the prevalence of each component of MetS in the population of Yogyakarta Special Region, Indonesia 


\section{MATERIALS AND METHODS}

\section{Subjects}

This retrospective study was based on IFLS survey conducted by RAND foundation, the Center for Population and Policy Studies (CPPS) of Universitas Gadjah Mada, Yogyakarta and Survey METER in year 2007. The research protocol of the data collection methods can be found in the IFLS4 working paper volume 1 titled: "The Fourth Wave of the Indonesia Family Life Survey: Overview and Field Report". 9 The data for this study was from Yogyakarta Special Region collected by random stratification method and obtained from the RAND organization website. Within the raw data, the measurements needed were the number of subjects, age, gender, waist circumference (WC), high density lipoprotein cholesterol (HDL-C), high sensitivity C-Reactive Protein (hsCRP) level, height, weight, Body Mass Index (BMI), systolic and diastolic blood pressure. These data were obtained from the books labelled US1, US2, and $\mathrm{K}$. The laboratory examination especially hsCRP was conducted in Department of Clinical Pathology and Laboratory Medicine, Faculty of Medicine, Universitas Gadjah Mada Yogyakarta using dried-blood samples of research subject by ELISA method.

\section{Procedure}

A total of 3560 respondents from Yogyakarta Special Region were included in the survey with inclusion criteria as follows: the population of Yogyakarta Special Region involved in the IFLS 4 longitudinal survey, aged 40 years old and above, which had had their blood pressure, waist circumference, HDL-C level, standing height and weight, and hsCRP levels be measured. The subjects involved also had their medication history for previously diagnosed diseases. Inclusion criteria were subjects aged 40 and above residing in Yogyakarta Special Region selected according to the IFLS 4 study, because WC and HDL-C data were not available for subjects $<40$ years old. Exclusion criteria were subjects with incomplete data of the research variables/risk factors (with the exclusion of hsCRP where only a subset of subjects were chosen to have data collected) and pregnant subjects.

From a total of 3560 subject in IFLS 4 survey residing in Yogyakarta Special Region, after filtering the population based on our inclusion criteria, a final sum of 766 eligible subjects were used for our study and further analysis. Based on IDF criteria, the subject was defined as having MetS if they had central obesity (if BMI $>30 \mathrm{~kg} / \mathrm{m}^{2}$ or WC in male $\geq$ $90 \mathrm{~cm}$ and in female $\geq 80 \mathrm{~cm}$ ) plus 2 of the following 3 factors: reduced HDL cholesterol (serum HDL-C $<40 \mathrm{mg} / \mathrm{dL}$ in male, $<50 \mathrm{mg} / \mathrm{dL}$ in females or treatment for lipid abnormality), raised blood pressure/hypertension (systolic blood pressure $\geq 130 \mathrm{mmHg}$ or diastolic blood pressure $\geq 85 \mathrm{mmHg}$ or treatment of previously diagnosed hypertension), and having insulin resistance that indirectly determined by previously diagnosed or having treatment for diabetes, also subject having pro inflammatory state $(\mathrm{hsCRP}>3 \mathrm{mg} / \mathrm{dL}) .^{10}$

Demographic parameter classification was as follows: gender was defined as male or female, ${ }^{9}$ age was classified into pre-elderly (40-59 years old) and elderly (60 years old and above), ${ }^{11}$ ethnicity was classified into Javanese and non-Javanese ethnic groups ${ }^{9}$ and geographic factor was classified into urban and rural status. ${ }^{9}$ The limitation of this study was no measurement taken for triglyceride levels in blood in the IFLS while high triglyceride levels was one of the criteria for MetS diagnosis, we could not use triglyceride 
Hao Jian et al., Prevalence of metabolic syndrome and its components based on International Diabetes Federation (IDF) definition in Yogyakarta Special Region, Indonesia

level as one of the criteria to determine MetS in our study, so this parameter was excluded from our diagnostic criteria for MetS.

\section{Statistical analysis}

Data was analyzed using Stata v12.0 format software. The variables stated were analyzed using univariate, bivariate. In the univariate analysis, the prevalence of each component of MetS were tabulated in the form of mean or $\%$ for each of the components. In the bivariate analysis, t-test and chi-square were employed to evaluate the difference of the MetS components caused by demographic factors and their statistical significance. Prevalence of MetS based on each demographic factor was also determined. Significance level of $p<0.05$ was applied and $95 \%$ CI was observed.

\section{RESULTS}

The characteristic of eligible subjects $(n=766)$ from Yogyakarta Special Region population in this study is showed in TABLE 1. Out of 766 subjects, $363(47.39 \%)$ were males and $403(52.61 \%)$ were females. Subjects were classified according to age group, ethnicity, and geographic factor. The mean age was 57.49, which also means that the population had a larger proportion of pre-elderly (58.22\%) than elderly (41.78\%) (TABLE 1$)$. Only 10 out of the total 766 subjects were not Javanese, hence the percentage of non-Javanese involved in this study was a mere $1.31 \%$ (TABLE 1 ). Most of the study population resided in urban areas $(71.93 \%)$ (TABLE 1). Mean systolic $\mathrm{BP}$ and diastolic BP were 137.65 and 80.55 $\mathrm{mm} \mathrm{Hg}$ respectively, reflecting high systolic blood pressure among subjects (TABLE 1). Only 10 subjects had recorded treatment of hypertension, 3 subjects were being treated for dyslipidemia, and 6 subjects had diabetes treatment, illustrating either inadequate collection of treatment data, or a very healthy population.

TABLE 1. Caracteristic of eligible subject from Yogyakarta Special Region population $(\mathrm{n}=766)$

\begin{tabular}{|c|c|}
\hline Characteristic & Number \\
\hline \multicolumn{2}{|l|}{$\begin{array}{l}\text { Metabolic Syndrome } \\
{[\mathrm{n}(\%)]}\end{array}$} \\
\hline - Present & $101(13.19)$ \\
\hline - Absent & $665(86.81)$ \\
\hline \multicolumn{2}{|l|}{ Gender $[\mathrm{n}(\%)]$} \\
\hline - Male & $363(47.39)$ \\
\hline - Female & $403(52.61)$ \\
\hline Age (mean \pm SD years $)$ & $57.49 \pm 13.33$ \\
\hline \multicolumn{2}{|l|}{ Age Group } \\
\hline - Pre-Elderly & $446(58.22)$ \\
\hline - Elderly & $320(41.78)$ \\
\hline \multicolumn{2}{|l|}{ Ethnicity (\%) } \\
\hline - Javanese & $756(98.69)$ \\
\hline - Others & $10(1.31)$ \\
\hline \multicolumn{2}{|l|}{ Geographic factor [n (\%)] } \\
\hline - Rural & $215(28.07)$ \\
\hline - Urban & $551(71.93)$ \\
\hline \multicolumn{2}{|l|}{ Anthropometric parameter } \\
\hline - Height (mean \pm SD m) & $1.54 \pm 0.09$ \\
\hline - Weight (mean \pm SD kg) & $53.12 \pm 12.01$ \\
\hline - $\mathrm{BMI}\left(\right.$ mean $\left.\pm \mathrm{SD} \mathrm{kg} / \mathrm{m}^{2}\right)$ & $22.42 \pm 4.24$ \\
\hline - $\mathrm{WC}($ mean $\pm \mathrm{SD}$ cm $)$ & $79.35 \pm 11.50$ \\
\hline \multicolumn{2}{|l|}{ Blood pressure } \\
\hline $\begin{array}{l}\text { - Systolic BP (mean } \pm \text { SD } \\
\text { mmHg) }\end{array}$ & $137.65 \pm 24.35$ \\
\hline $\begin{array}{l}\text { - Diastolic } \mathrm{BP}(\text { mean } \pm \mathrm{SD} \\
\mathrm{mmHg})\end{array}$ & $80.55 \pm 11.80$ \\
\hline $\begin{array}{l}\text { History of hypertension } \\
\text { treatment }[\mathrm{n}(\%)]\end{array}$ & $10(1.31)$ \\
\hline \multicolumn{2}{|l|}{ Lipid profile } \\
\hline $\begin{array}{l}\text { - HDL-c (mean } \pm \text { SD mg/ } \\
\mathrm{dL})\end{array}$ & $43.99 \pm 16.70$ \\
\hline $\begin{array}{l}\text { - Dyslipidemia treatment } \\
{[\mathrm{n}(\%)]}\end{array}$ & $3(0.39)$ \\
\hline Diabetes treatment $[\mathrm{n}(\%)]$ & $6(0.78)$ \\
\hline hsCRP $($ mean $\pm \mathrm{SD} \mathrm{mg} / \mathrm{L})$ & $2.26 \pm 3.41$ \\
\hline
\end{tabular}


The males were on average taller than the females $(1.60 \mathrm{~m}$ for males vs $1.48 \mathrm{~m}$ for females), and also heavier than the females (55.60 kg for males vs $50.88 \mathrm{~kg}$ for females). The average BMI of males was lower than females, with the values of $21.71 \mathrm{~kg} / \mathrm{m}^{2}$ and $23.06 \mathrm{~kg} / \mathrm{m}^{2}$ respectively. It was intriguing to find that in females, the HDL-C is higher than males, with an average of $37.02 \mathrm{mg} / \mathrm{dL}$ for males and $50.26 \mathrm{mg} / \mathrm{dL}$ for females (TABLE 4). The prevalence of MetS obtained from this study was $13.19 \%$ (TABLE 1). There was a higher prevalence of MetS among the females compared to the males (15.88 vs $10.19 \%$ ), pre-elderly compared to the elderly (13.90 vs $12.19 \%$ ), Javanese compared to other ethnicities (13.23 vs $10.00 \%)$, and urban compared to rural population (15.06 vs $8.37 \%$ ) (TABLE 2).

TABLE 2. Prevalence of MetS based on demographic factor

\begin{tabular}{lc}
\hline \multicolumn{1}{c}{ Variables } & Met S Prevalence $(\%)$ \\
\hline Sex & $\cdot 10.19$ \\
• Male & $\bullet 15.88$ \\
• Female & \\
Age group & $\bullet 13.90$ \\
• Pre-elderly & $\bullet 12.19$ \\
• Elderly & \\
Ethnicity & $\bullet 13.23$ \\
- Javanese & $\bullet 10.00$ \\
• Others & \\
Geographic factor & $\bullet 15.06$ \\
- Urban & $\bullet 8.37$ \\
\hline Rural &
\end{tabular}

The prevalence of each MetS component was as follows: central obesity, $32.38 \% \quad(n=248)$; hypertension, $60.44 \% \quad(\mathrm{n}=463)$; dyslipidemia, $56.27 \%(\mathrm{n}=431)$; insulin resistance, $0.78 \%(\mathrm{n}=6)$; and pro-Inflammatory state, $15.71 \% \quad(\mathrm{n}=33)$ (TABLE 3).

TABLE 3. Prevalence of each MetS component

\begin{tabular}{lc}
\hline MetS Component & Prevalence (\%) \\
\hline Central obesity & 32.38 \\
Hypertension & 60.44 \\
Dyslipidemia & 56.27 \\
Insulin resistance* & 0.78 \\
Pro-inflammatory & 15.71 \\
state** \\
\hline * Insulin resistance data was solely deter- \\
mined by diabetes treatment; ** Only 210 \\
subjects have data for hsCRP data. Pro-in- \\
$\begin{array}{l}\text { flammatory state is present when levels are } \\
\text { higher than the cut-off point of 3.0 mg/dL. }\end{array}$
\end{tabular}


Hao Jian et al., Prevalence of metabolic syndrome and its components based on International Diabetes Federation (IDF) definition in Yogyakarta Special Region, Indonesia

TABLE 4. Characteristics of MetS components based on sex

\begin{tabular}{lccc}
\hline \multicolumn{1}{c}{ Characteristic } & Male $(\mathrm{n}=363)$ & Female $(\mathrm{n}=403)$ & $\mathrm{p}^{*}$ \\
\hline Height $($ mean $\pm \mathrm{SD} \mathrm{m})$ & $1.60 \pm 0.10$ & $1.48 \pm 0.07$ & $<0.0001$ \\
Weight $($ mean $\pm \mathrm{SD} \mathrm{kg})$ & $55.60 \pm 11.50$ & $50.88 \pm 12.03$ & $<0.0001$ \\
BMI $\left(\right.$ mean $\left.\pm \mathrm{SD} \mathrm{kg} / \mathrm{m}^{2}\right)$ & $21.71 \pm 3.74$ & $23.06 \pm 4.56$ & $<0.0001$ \\
WC $($ mean $\pm \mathrm{SD} \mathrm{cm})$ & $79.45 \pm 10.88$ & $79.25 \pm 12.05$ & 0.8121 \\
$\begin{array}{l}\text { HDL-C }(\text { mean } \pm \mathrm{SD} \\
\text { mg/dL) }\end{array}$ & $37.02 \pm 14.30$ & $50.26 \pm 16.22$ & $<0.0001$ \\
$\begin{array}{l}\text { Systolic BP }(\text { mean } \pm \mathrm{SD} \\
\text { mmHg) }\end{array}$ & $137.56 \pm 24.02$ & $137.74 \pm 24.68$ & 0.9222 \\
$\begin{array}{l}\text { Diastolic BP }(\mathrm{mean} \pm \\
\text { SD mmHg) }\end{array}$ & $81.30 \pm 11.56$ & $79.88 \pm 11.98$ & 0.0957 \\
$\begin{array}{l}\text { hsCRP }(\text { mean } \pm \mathrm{SD} \\
\text { mg/L) }\end{array}$ & $2.05 \pm 2.83$ & $2.41 \pm 3.79$ & 0.4507 \\
$\begin{array}{l}\text { Treatment for } \\
\text { hypertension [n or }(\%)]\end{array}$ & $5(1.38)$ & $5(1.24)$ & 0.5650 \\
$\begin{array}{l}\text { Treatment for diabetes } \\
\text { [n or }(\%)]\end{array}$ & $3(0.83)$ & $3(0.74)$ & 0.5690 \\
$\begin{array}{l}\text { Treatment for } \\
\text { dyslipidemia [n or }(\%)]\end{array}$ & $3(0.83)$ & $0(0)$ & 0.1070 \\
\hline
\end{tabular}

* Significantly different if $\mathrm{p}<0.05$

Pre-elderly subjects had heavier weight $(57.46 \mathrm{~kg})$, resulting in a higher BMI $(23.57$ $\mathrm{kg} / \mathrm{m}^{2}$ ), which also correlated with the high WC $(81.78 \mathrm{~cm})$. The weight, BMI, and WC of the elderly population on the other hand, had means of $57.46 \mathrm{~kg}, 23.57 \mathrm{~kg} / \mathrm{m}^{2}$ and $81.78 \mathrm{~cm}$ respectively. The mean systolic blood pressure was $130.04 \mathrm{mmHg}$ for preelderly and $148.27 \mathrm{mmHg}$ for elderly. A higher systolic blood pressure was evident in the elderly (TABLE 5). There were only 10 subjects in the non-Javanese group, resulting in no significant difference in all the variables analyzed (TABLE 6). 
TABLE 6. Characteristics of MetS components based on ethnicity

\begin{tabular}{|c|c|c|c|}
\hline Characteristic & Javanese $(n=363)$ & Other $(n=403)$ & $\mathrm{p}^{*}$ \\
\hline Height (mean \pm SD m) & $1.57 \pm 0.09$ & $1.54 \pm 0.09$ & 0.8175 \\
\hline Weight (mean \pm SD kg) & $53.10 \pm 12.06$ & $54.43 \pm 7.28$ & 0.7281 \\
\hline $\mathrm{BMI}\left(\right.$ mean $\left.\pm \mathrm{SD} \mathrm{kg} / \mathrm{m}^{2}\right)$ & $22.41 \pm 4.25$ & $23.05 \pm 3.68$ & 0.6391 \\
\hline $\mathrm{WC}($ mean $\pm \mathrm{SD} \mathrm{cm})$ & $79.31 \pm 11.53$ & $82.45 \pm 8.77$ & 0.3908 \\
\hline $\begin{array}{l}\text { HDL-C (mean } \pm \text { SD mg/ } \\
\text { dL) }\end{array}$ & $43.92 \pm 16.63$ & $49.10 \pm 21.26$ & 0.3302 \\
\hline $\begin{array}{l}\text { Systolic BP (mean } \pm \mathrm{SD} \\
\mathrm{mmHg})\end{array}$ & $137.47 \pm 24.17$ & $151.37 \pm 34.59$ & 0.0731 \\
\hline $\begin{array}{l}\text { Diastolic BP (mean } \pm \text { SD } \\
\mathrm{mmHg})\end{array}$ & $80.48 \pm 11.75$ & $86.27 \pm 14.04$ & 0.1231 \\
\hline $\mathrm{hsCRP}($ mean $\pm \mathrm{SD} \mathrm{mg} / \mathrm{L})$ & $2.28 \pm 3.43$ & $1.10 \pm 0.45$ & 0.5552 \\
\hline $\begin{array}{l}\text { Treatment for hypertension } \\
{[\mathrm{n} \text { or }(\%)]}\end{array}$ & $10(1.32)$ & $0(0)$ & 0.9290 \\
\hline $\begin{array}{l}\text { Treatment for diabetes }[\mathrm{n} \\
\text { or }(\%)]\end{array}$ & $6(0.79)$ & $0(0)$ & 0.9540 \\
\hline $\begin{array}{l}\text { Treatment for dyslipidemia } \\
{[\mathrm{n} \text { or }(\%)]}\end{array}$ & $3(0.40)$ & $0(0)$ & 0.9740 \\
\hline
\end{tabular}

* Significantly different if $\mathrm{p}<0.05$

There was a slight difference in urban and rural mean height, being $1.54 \mathrm{~m}$ and $1.52 \mathrm{~m}$ respectively. However, the weight in urban population was significantly higher compared to rural, with 54.87 for the urban average and 48.63 for the rural average. From this data, as accounted from the higher average weight, the BMI was 1.85 units higher in the urban population $\left(22.94 \mathrm{~kg} / \mathrm{m}^{2}\right)$ compared to the rural population $\left(21.09 \mathrm{~kg} / \mathrm{m}^{2}\right)$. The mean waist circumference was also higher in the urban population $(81.48 \mathrm{~cm})$ compared to the rural population $(73.89 \mathrm{~cm})$. However, the rural population had lower HDL-c values compared to the urban population (40.48 $\mathrm{mg} / \mathrm{dL}$ for rural and $45.36 \mathrm{mg} / \mathrm{dL}$ for urban) (TABLE 7). 
Hao Jian et al., Prevalence of metabolic syndrome and its components based on International Diabetes Federation (IDF) definition in Yogyakarta Special Region, Indonesia

TABLE 7. Characteristic of MetS components based on geographic factor

\begin{tabular}{lccc}
\hline Characteristic & Male $(\mathrm{n}=363)$ & Female $(\mathrm{n}=403)$ & $\mathrm{p}^{*}$ \\
\hline Height $($ mean $\pm \mathrm{SD} \mathrm{m})$ & $1.52 \pm 0.09$ & $1.54 \pm 0.08$ & $<0.0001$ \\
Weight $($ mean $\pm \mathrm{SD} \mathrm{kg})$ & $48.63 \pm 10.25$ & $54.87 \pm 12.21$ & $<0.0001$ \\
$\mathrm{BMI}\left(\mathrm{mean} \pm \mathrm{SD} \mathrm{kg} / \mathrm{m}^{2}\right)$ & $21.09 \pm 3.64$ & $22.94 \pm 4.35$ & $<0.0001$ \\
WC $($ mean $\pm \mathrm{SD} \mathrm{cm})$ & $73.89 \pm 10.13$ & $81.48 \pm 11.31$ & $<0.0001$ \\
HDL-C $(\mathrm{mean} \pm \mathrm{SD} \mathrm{mg} / \mathrm{dL})$ & $40.48 \pm 14.86$ & $45.36 \pm 17.18$ & 0.0003 \\
Systolic BP $(\mathrm{mean} \pm \mathrm{SD} \mathrm{mmHg})$ & $139.79 \pm 24.21$ & $136.82 \pm 24.38$ & 0.1298 \\
Diastolic BP $($ mean $\pm \mathrm{SD} \mathrm{mmHg})$ & $80.21 \pm 11.46$ & $80.68 \pm 11.93$ & 0.6203 \\
hsCRP $(\mathrm{mean} \pm \mathrm{SD} \mathrm{mg} / \mathrm{L})$ & $2.23 \pm 4.32$ & $2.27 \pm 3.13$ & 0.9426 \\
Treatment for hypertension $[\mathrm{n}$ or & $3(1.40)$ & $7(1.27)$ & 0.2740 \\
$(\%)]$ & & & \\
Treatment for diabetes $[\mathrm{n}$ or $(\%)]$ & $3(1.40)$ & $2(0.54)$ & 0.1340 \\
Treatment for dyslipidemia $[\mathrm{n}$ or & $1(0.47)$ & & 0.2710 \\
$(\%)]$ & & & \\
\hline * Significantly different if $\mathrm{p}<0.05$ & & & \\
\hline
\end{tabular}

\section{DISCUSSION}

Worldwide prevalence of MetS ranged from $<10 \%$ to $84 \% .^{12}$ The prevalence of MetS in Asian countries were: Singapore, 18\%; Philippines, 19\%; Hong Kong, 22\%; and China, $26 \%$. Meanwhile the prevalence of MetS in various region of Indonesia was ranging between $18-34 \%$, accordingly. ${ }^{3-6,13}$ The prevalence of MetS in Yogyakarta Special Region (13.19\%) was lower compared to other countries, or event with other region in Indonesia, indicating that people in Yogyakarta Special Region in this study might had lower cardiovascular risk and possibly healthier life style than in other region in Indonesia.

The higher BMI of females in this study supported the observation of higher prevalence of obesity in females of developing countries. ${ }^{14}$ According to the study conducted by Low et al. ${ }^{14}$ there was an increasing trend of obesity with age, where the peak prevalence was reached at around 40-50 years old and drops thereafter in developing countries.
This corresponds well to the result obtained in this study where pre-elderly subjects had higher weight, BMI and WC compared to the elderly population. The analysis conducted for BMI, and WC based on geographic factor also in agreement with the trend of increased prevalence of obesity in urban areas compared to rural areas in developing countries. ${ }^{14}$ In Yogyakarta Special Region, central obesity was more likely in females, pre-elderly, and urban populations.

Central obesity, or less commonly known as abdominal obesity was the main driver behind the progression of MetS in people. Evidence showed patients with CVD often had central obesity, and it had also been targeted to predict adverse metabolic or cardiovascular outcomes. Exacerbation of insulin resistance and other cardiometabolic risk factors, coupled with altered secretions of adipokines forms the mechanistic relationship between obesity and MetS. ${ }^{15}$ 
The importance of this factor has been realized by the IDF and therefore was named a compulsory component of MetS. ${ }^{10}$ Prevalence of central obesity has been rising in developing countries, due to rapid urbanization where a positive energy balance was made present resulting from sedentary lifestyles and energydense diets. ${ }^{15}$ The majority of Yogyakarta Special Region citizens stay in the city $(71.93 \%)$, so this trend of obesity and MetS may increase exponentially with urbanization and the rise of the middle-class in the near future.

The biologic difference of HDL-C levels between males and females might be explainable by the high levels of androgens in males and the cardioprotective effect of estrogen in females. ${ }^{16}$ This theory was supported by the findings of this study where females had a higher HDL-C level than their male counterparts. The significant mean difference of $13.24 \mathrm{mg} / \mathrm{dL}$ between females and male HDL-C levels in this current study should be explored further in other researches. Previous study conducted by Hatma showed only $5.09 \mathrm{mg} / \mathrm{dL}$ mean difference between females and males of Javanese descent. ${ }^{17}$ The phenomenon of the rural population having lower HDL-C values compared to the urban population in this study was consistent with the findings in a Thai study. ${ }^{18}$ The lower HDL-C in the rural population also supported the evidence that residents of the rural area typically had higher TG levels and lower HDL-C levels, whereas residents of the urban area had higher total cholesterol levels and LDL-C levels. ${ }^{19}$

The high triglyceride, low HDL-C levels that characterize dyslipidemia has high prognostic importance as recognized by MetS defining criteria. Risk increment for dyslipidemic subjects to have MetS was quite similar across definitions therefore should be added as a standard health measurement if possible (NCEP/ATP III and WHO). ${ }^{20}$ The elderly had significantly higher systolic blood pressure compared to pre-elderly, which indicated that this can be used as a good predictor for MetS in the elderly. This finding agreed with the significant gradual increased in prevalence of hypertension with age in the HUNT 2 study. ${ }^{21}$

Females had higher hsCRP levels (2.41 vs $2.05 \mathrm{mg} / \mathrm{L}$ ) than males (TABLE 4). Menopause occured in the pre-elderly population and because this population was larger in this study, it could be due to taking hormone replacement therapy that the mean hsCRP for females were higher. ${ }^{22}$ Levels of CRP were higher among women than among men and increase with age in the United States. ${ }^{23}$ Recent research has started contemplating the use of a new cut-off of $2 \mathrm{mg} / \mathrm{L}$ for CRP assessment. There was a higher prevalence of MetS among the females compared to the males $(15.88 \mathrm{vs}$ $10.19 \%$ ), pre-elderly compared to the elderly ( 13.90 vs $12.19 \%$ ), Javanese compared to other ethnicities (13.23 vs $10.00 \%$ ), and urban compared to rural population (15.06 vs $8.37 \%$ ). The higher prevalence in females was consistent with studies conducted in Jakarta, Bali, and Bogor., ${ }^{5,6}$ The drop in prevalence in the elderly was also agreed with a study conducted by Kamso. However, the difference in prevalence in this study $(13.90 \%$ vs $12.19 \%$ ) was not as large as in Kamso's study $(46.6 \%$ vs $19.2 \%) .{ }^{24}$ The difference of prevalence between Javanese and other ethnicity was not worth mentioning due to statistical insignificance. Corresponding to the other studies in Indonesia, this study also agreed that the prevalence of MetS in urban population was higher $(15.06 \%$ vs $8.37 \%))^{5,6}$

The prevalence of the respective individual components of Mets among MetS group in this study in descending order, 
Hao Jian et al., Prevalence of metabolic syndrome and its components based on International Diabetes Federation (IDF) definition in Yogyakarta Special Region, Indonesia

were: hypertension (60.44\%), dyslipidemia $(56.27 \%)$, central obesity $(32.38 \%)$, proinflammatory state $(15.71 \%)$ and insulin resistance $(0.78 \%)$. These results indicated that approximately 2-3 people out of 5 with MetS would have hypertension and/or dyslipidemia, and 1 out of 3 people with MetS would have central obesity. Hypertension was the most prevalent factor for MetS across all studies done in Indonesia, including this study. Based on RISKESDAS 2013, the regional prevalence of hypertension was $25.7 \%$, with the cut-off point of $\geq 140 / 90 \mathrm{mmHg}$, which was lower compared to $60.44 \%$ prevalence in this study, which had a lower cut-off point $(\geq 130 / 85 \mathrm{mmHg})$. There are 2 possibilities for this phenomenon, one being that there are a lot of people in the $130-140 / 85-90 \mathrm{mmHg}$ blood pressure range and the other possibility being there is a decrease in hypertension in the population between IFLS 4 data collection and RISKESDAS 2013 data collection time period.

Likely reasons explaining the high prevalence of hypertension, dyslipidemia and central obesity in citizens of Yogyakarta Special Region are their lack of knowledge, attitude and behavior regarding healthy lifestyle and habits. Unhealthy behaviors of Yogyakarta Special Region citizens included: smoking $(26.9 \%)$, low physical activity $(20.8 \%)$, sedentary activity $(42.1 \%)$, and consumption of sweet, salty, and oily food $(69.2 \%, 12.4 \%, 50.7 \%){ }^{25}$ Smoking prevalence in Yogyakarta Special Region reduced slightly, from $29.8 \%$ to $26.9 \%{ }^{8}$ Low physical activity and sedentary activity was one of the side effects of urbanization and the rise of the middle-class where people get lazy to have regular physical activity, and consume energy-dense foods, creating an energy surplus which in the end gets converted into adipose tissue, causing central obesity and MetS. ${ }^{15}$
The prevalence of sweet food consumption in Yogyakarta Special Region was high. Preference for a high sugar intake is linked to obesity, hypertension, and the metabolic syndrome, but causation has yet to be proven.

Limitations of this study should be considered, because in this study, data for 1 out of 4 of the factors required to define MetS in the IDF criterion was not available, namely triglyceride levels. Furthermore, raised fasting plasma glucose was only determined by data of usage of medicine for diabetes. These 2 limitations of data collection might have impaired the ability of the criterion to detect the full spectrum of patients with MetS, therefore only detecting those having MetS that also had reduced HDL-C, raised blood pressure, or were taking medicine for dyslipidemia, hypertension or diabetes. It was possible, that a large amount of subjects had raised triglycerides, or had undetected raised fasting plasma glucose, both of which may cause a large amount of MetS negative subjects to be re-classified as having MetS if the values of said factors were to be collected. As shown in TABLE 3, the number of non-Javanese involved in this study was only 10 , causing most of the analysis on ethnical differences between Javanese and non-Javanese to not be statistically significant. Finally, this study did not include subjects less than 40 years old, so prevalence of MetS in childhood and adulthood were excluded in this study.

Metabolic syndrome patients have an increased risk of CHD death and all-cause mortality. It is well established that CHD, CVD, and total mortality are predicted more strongly by MetS than by individual factors. Subjects with 1 or 2 MetS factors positive are at 2-fold greater risk of CHD and CVD mortality, therefore, unless all the risk factors are absent, the risk cannot be optimal. Based on the Framingham Risk Score, more 
than $40 \%$ of patients with MetS were at intermediate risk (10-20\% 10-year risk), and another $40 \%$ were at high risk $(>20 \% 10$-year risk) of CHD. According to WHO, diabetes and cardiovascular diseases contributed $6 \%$ and $37 \%$ respectively to Indonesia's national proportional mortality, resulting in $43 \%$ of deaths to be attributable to these 2 types of diseases. ${ }^{26}$

From the economical viewpoint, Indonesia is expected to face a $\$ 4.47$ trillion loss due to NCDs ( $\$ 17,863$ per capita) from 2012 through 2030. Diabetes and CVD scales to an output loss of 0.2 and 1.77 trillion US\$ respectively, which sum is close to half of this loss. Cardiovascular disease and diabetes accounts for $44.1 \%$ of Indonesia's overall loss of GDP output from the year 2012 to $2030 .^{27}$ In other countries, many approaches to reduce and prevent MetS have been employed. For example, in the Finnish Diabetes Prevention Study, subjects received individualized dietary counseling, were given resistance training sessions, were motivated to increase overall physical activity, had voluntary group sessions, expert lectures, low-fat cooking lessons, visits to local supermarkets, and also between-visit phone calls and letters. The individualized approach had been used in this study of 3.9 years, and significant reduction in MetS and abdominal obesity prevalence was observed (OR 0.62, 0.48). ${ }^{28}$ Another attempt at lifestyle modification was observed in the 'Red Ruby' study, where an interactive webbased intervention was used. The intervention group received an interactive Healthy Heart Profile and an individualized calorie restricted diet. The benefit of this intervention was that the participants could apply the interventions at a convenient time and place, and it was easy to monitor self-progress, as well as being individualized. $^{29}$

\section{CONCLUSION}

The prevalence of MetS in Yogyakarta Special Region is $13.19 \%$ with hypertension and dyslipidemia as the most common components.

\section{REFERENCES}

1. Alberti KG, Zimmet P, Shaw J. Metabolic syndrome--a new world-wide definition. A consensus statement from the international diabetes federation. Diabet Med 2006; 23(5):469-80. http://dx.doi.org/10.1111/ j.1464-5491.2006.01858.x

2. Yu S, Guo X, Yang $H$, Zheng L, Sun Y. An update on the prevalence of metabolic syndrome and its associated factors in rural northeast China. BMC Public Health 2014; 14(1):877. http://dx.doi.org/10.1186/14712458-14-877

3. Suastika K, Dwipayana P, Saraswati IMR, Gotera W, Budhiarta AGD, Sutanegara IND, et al. Prevalence of obesity, metabolic syndrome, impaired fasting glycaemia, and diabetes in selected villages of Bali, Indonesia. JAFES 2011; 26(2): 159-62. http:// dx.doi.org/10.15605/jafes.026.02.14

4. Sirait AM \& Sulistiowati E. Sindrom metabolik pada orang dewasa di kota bogor, 2011-2012. Media Litbangkes 2014; 24(2):81-8. http://dx.doi.org/10.22435/ mpk. v24i2.3565.81-88

5. Soewondo P, Purnamasari D, Oemardi M, Waspadji S, Soegondo S. Prevalence of metabolic syndrome using NCEP/ATP III criteria in Jakarta, Indonesia: the Jakarta primary non-communicable disease risk factors surveillance 2006. Acta Med Indones 2010; 42(4):199-203.

6. Pranoto A, Kholili U, Tjokroprawiro A, Sutjahyo A, Murtiwi S, Adi S, et al. Metabolic syndrome as observed in Surabaya. Abstract. In : Tjokroprawiro A, eds. Surabaya 
Hao Jian et al., Prevalence of metabolic syndrome and its components based on International Diabetes Federation (IDF) definition in Yogyakarta Special Region, Indonesia

metabolic syndrome update-1. Surabaya; 2005; 245-7.

7. Dinas Kesehatan DIY. Profil Kesehatan Daerah Istimewa Yogyakarta Tahun 2013, Yogyakarta: Dinas Kesehatan DIY, 2013.

8. Badan Penelitian dan Pengembangan Kesehatan, Departemen Kesehatan RI. Riset Kesehatan Dasar (RISKESDAS) 2007. Jakarta: Badan Penelitian dan Pengembangan Kesehatan, Departemen Kesehatan RI, 2008.

9. Strauss J, Witoelar F, Sikoki B, Wattie AM. The Fourth Wave of the Indonesia family life survey: overview and field report. Work Paper 2009; 1:1-87.

10. International Diabetes Federation. The IDF Consensus Worldwide definition of the Metabolic Syndrome. In: Alberti KGMM, Zimmet PZ, Shaw J, Grundy SM, editors. The IDF Consensus Worldwide definition of the Metabolic Syndrome. 2006.

11. Badan Pusat Statistik RI. Statistik Penduduk Lanjut Usia. 2014, Jakarta: Badan Pusat Statistik RI, 2014.

12. Kaur J. A comprehensive review on metabolic syndrome. Cardiol Res Pract 2014; 2014:943162. http:/dx.doi. org $/ 10.1155 / 2014 / 943162$

13. NestelP, Lyu R, Low LP, Sheu WH, Nitiyanant W, Saito I, et al. Metabolic syndrome: recent prevalence in East and Southeast Asian populations. Asia Pac J Clin Nutr 2007; 16(2):362-7.

14. Low S, Chin MC, Deurenberg-Yap M. Review on epidemic of obesity. Ann Acad Med Singapore 2009; 38(1):57-9.

15. Després JP. Abdominal obesity: The most prevalent cause of the metabolic syndrome and related cardiometabolic risk. Eur Hear J Suppl 2006; 8(suppl_B):4-12. http://dx.doi.org/10.1093/eurheartj/sul002

16. Rossouw J. Hormones, genetic factors, and gender differences in cardiovascular disease.
Cardiovasc Res 2002; 53(3):550-7. http:// dx.doi.org/10.1016/S0008-6363(01)00478-3

17. Hatma RD. Lipid profiles among diverse ethnic groups in Indonesia. Acta Med Indones 2011; 43(1):4-11.

18. Pongchaiyakul C, Hongsprabhas $\mathrm{P}$, Pisprasert V, Pongchaiyakul C. Rural-urban difference in lipid levels and prevalence of dyslipidemia: a population-based study in Khon Kaen province, Thailand. J Med Assoc Thai 2006; 89(11):1835-44.

19. Sartika RA. Dietary trans fatty acids intake and its relation to dyslipidemia in a sample of adults in Depok city, West Java, Indonesia. Malays J Nutr 2011; 17(3):337-46.

20. Rodriguez A, Delgado-Cohen H, Reviriego J, Serrano-Rios M. Risk factors associated with metabolic syndrome in type 2 diabetes mellitus patients according to World Health Organization, Third Report National Cholesterol Education Program, and International Diabetes Federation definitions. Diabetes Metab Syndr Obes 2010; 4:1-4. http://dx.doi.org/10.2147/DMSOTT.S13457

21. Hildrum B, Mykletun A, Hole T, Midthjell $\mathrm{K}$, Dahl AA. Age-specific prevalence of the metabolic syndrome defined by the International Diabetes Federation and the National Cholesterol Education Program: the Norwegian HUNT 2 study. BMC Public Health 2007; 7:220. http://dx.doi. org/10.1186/1471-2458-7-220

22. Ridker PM. Cardiology Patient Page. C-reactive protein: a simple test to help predict risk of heart attack and stroke. Circulation $2003 ; 108(12): 81-5$.

http://dx.doi.org/10.1161/01. CIR.0000093381.57779.67

23. Woloshin S, Schwartz LM. Distribution of C-reactive protein values in the United States. N Engl J Med 2005; 352(15):1611-3. http:// dx.doi.org/10.1056/NEJM200504143521525 
24. Kamso S. Body mass index, total cholesterol, and ratio total to $\mathrm{HDL}$ cholesterol were determinants of metabolic syndrome in the Indonesian elderly. Med J Indones 2007; 16(3):195-200. http://dx.doi.org/10.13181/ mji.v16i3.276

25. Badan Penelitian dan Pengembangan Kesehatan, Departemen Kesehatan RI. Riset Kesehatan Dasar (RISKESDAS) 2013. Jakarta: Badan Penelitian dan Pengembangan Kesehatan, Departemen Kesehatan RI, 2014.

26. World Health Organization. Noncommunicable Diseases (NCD) Country Profiles: Indonesia. 2014; Geneva: World Health Organization, 2014.

27. Bloom DE, Chen S, McGovern M, Prettner $\mathrm{K}$, Candeias V, Bernaert A, et al. Economics of Diseases in Indonesia. World Econ Forum, 2015.

28. Lindstrom J, Louheranta A, Mannelin M, Rastas M, Salminen V, Eriksson J, et al. The finnish diabetes prevention study (DPS): Lifestyle intervention and 3-year results on diet and physical activity. Diabetes Care 2003; 26(12):3230-6. http://dx.doi.org/10.2337/ diacare.26.12.3230

29. Jahangiry L, Shojaeizadeh D, Najafi M, Mohammad K, Farhangi MA, Montazeri A. 'Red Ruby': an interactive web-based intervention for lifestyle modification on metabolic syndrome: a study protocol for a randomized controlled trial. BMC Public Healt 2014; 14:748. http://dx.doi. org/10.1186/1471-2458-14-748 